\title{
Middle School Mathematics Teachers' Opinions on Estimation
}

\author{
Burçak BOZ-YAMAN $^{* 1}$, Safure BULUT ${ }^{2}$ \\ ${ }^{1}$ Muğla Sıtkı Koçman University, Muğla, TURKEY, \\ ${ }^{2}$ Middle East Technical University, Ankara, TURKEY
}

Received : 09.06.2016

Accepted : 17.03.2017

\begin{abstract}
The purpose of the study is to investigate 5-8th grades mathematics teachers' opinions on estimation. The phenomenological research design is used. The semi-structured interviews were conducted with seven teachers who have been experienced in various mathematics curricula. According to analysis, definition of estimation, types of estimation, strategies of estimation, instructional activities in/out of the class, difficulties during teaching of estimation and importance of estimation are seven themes of the study. The results are revealed that most of the teachers could not define estimation and identify types and strategies of estimation. Even though they thought that estimation is an important skill for daily life but they do not provide appropriate teaching environments. The most important reason is that teachers do not believe the necessity of learning estimation, they think that estimations is not going to be asked in the national exams and they do not have enough competency about estimation.
\end{abstract}

Key words: estimation middle school mathematics teachers, mathematics curriculum.

\section{Summary}

\section{Introduction}

Estimation is a very popular mathematics ability in daily life. People use this skill even without being aware of it. For example, while shopping they can calculate the total amount of the items they purchase approximately or they can guess the number of people in a crowd. Although estimation had a relatively minor place in each mathematics education curricula since1968, 2009 elementary mathematics curriculum gave especially a great emphasis on estimation and this made it the center of interest. There are many types of estimation. These

\footnotetext{
* Corresponding Author: Burçak BOZ-YAMAN, Muğla Sitkı Koçman University, Faculty of Education, Department of Mathematics and Science Education, Muğla/TURKEY E-mail: burcak@mu.edu.tr
} 
can be listed as computational estimation, measurement estimation, numerosity, estimation of ambiguity with not enough data, a problem solving strategy. There are also lots of estimation strategies, some of them are; translation, reformulation, compensation, truncation, use compatible numbers, use last/first digits, etc. Although estimation and their strategies are a part of the mathematics curriculum for a long time, 2009 elementary mathematics curriculum is the first mathematics curriculum which gives the names of the strategies. The similar names of the strategies are also used the next mathematics curriculum which is 2013 mathematics curriculum. Estimation ability is a very important ability for student but according to many researches students are not that successful to use this ability. Most of the research studies on estimation have been interested in the students' achievement and strategies used in estimation questions. But the literature review reveals that the teachers' feeling and attitudes are also a factor of students' success in mathematics. Therefore teachers' feelings, thoughts and attitudes should be also investigated. Because of this, the aim of this study is to investigate middle school mathematics teachers' opinions about teaching estimation in their mathematics classes.

\section{Methodology}

In the current study, the researchers try to present teachers' opinions on estimation with respect to different mathematics curricula started from 1968. Phenomenological research design was used to present the teachers' opinions. A series of semi structured interviews have been conducted with seven selected teachers. The participants of the study were selected via purposive sampling with maximum variety criteria. The seven participants are teachers who employed different mathematics curricula in the different periods of their professional life. The five elementary school mathematics curricula (1968, 1983, 1990, 1998 and 2009) which are the teachers employed in their mathematics classes are examined to support the findings of the interviews. Based on the relevant literature, four themes have been constructed before the interviews and the interview questions were constructed based on these themes. However, during the interviews three more themes have emerged, so at the end, the following seven themes were taken into consideration for the analyses: 1) teachers' estimation definitions, 2) types of estimation, 3) estimation strategies, 4) the importance of estimation, 5) the instructional applications of estimation in/out of classroom, 6) the difficulty of estimation during teaching, and 7) the place of estimation in the mathematics curriculum. 


\section{Results and Discussion}

Since 1968 the national mathematics curricula have teaching objectives for the topic of estimation. This means that estimation has been a new topic neither for teachers nor for students for a long time. However, based on the interviews, it is realized that most of the teachers do not know what estimation is and what the strategies of each types of estimation are. In generally, teachers give definitions of estimation based on either computational or measurement estimation. They use the words "approximation, rounding, more or less" to explain the estimation and they do not think that the exact answer could not be an estimation. Teachers identify the types of estimation mainly in three categories; computational estimation, measurement estimation and reasoning in daily life situations. When the strategies are asked to teachers they could not give the name of the strategies but according to their explanation they use rounding for computational estimation most of the time, and benchmark is used for measurement estimation. Although they think that estimation is an important skill to gain for daily life they do not teach it by conducting proper educational techniques/materials. Because they believe that mathematics should only involve precise solutions but not rough or approximate solutions. Moreover, since estimation or approximate solutions are not involved in the test based national examinations; teachers do not prefer to conduct estimation based activities in their classroom. According to teachers, having adverse feelings about estimation is the only reason for having difficulties to teach estimation. They express that teachers do not believe in estimation should taught in mathematics classes. Although estimation is a part of the mathematics curriculum since 1968, yet some of them believe that estimation is not involved in mathematics curricula. These teachers give more important to exact computations in mathematics education.

\section{Conclusion}

The overall findings show that middle school mathematics teachers are aware of importance of the estimation in daily life but they do not believe that it should be taught in the mathematics courses. Although some of the teachers could observed that there were some computational estimation objectives in mathematics curriculum but they confused computational estimation with mental computation. On the other hand some other teachers could observe the measurement estimation related activities could be applied in the classroom but they prefer not to do these kinds of activities. They confessed that they do not believe the necessity of learning estimation, they think that estimations is not going to be asked in the national exams and they do not have enough competency about estimation. 


\title{
Ortaokul Matematik Öğretmenlerinin Tahmin Hakkındaki Görüşleri
}

\author{
Burçak BOZ-YAMAN ${ }^{\dagger 1}$, Safure BULUT² \\ ${ }^{1}$ Muğla Sıtkı Koçman Üniversitesi, Muğla/TÜRKİYE, \\ ${ }^{2}$ Ortadoğu Teknik Üniversitesi, Ankara/TÜRKİYE
}

Makale Gönderme Tarihi: 09.06.2016

Makale Kabul Tarihi: 17.03.2017

\begin{abstract}
Özet - $\mathrm{Bu}$ araştırmada 5-8. sınıflar matematik öğretmenlerinin tahmin becerisi hakkındaki görüşleri incelenmiştir. Çalışmada nitel araştırma desenlerinden olgu bilim kullanılmıştır. Farklı ilköğretim matematik dersi öğretim programlarında çeşitli deneyimlere sahip yedi öğretmen ile yarı-yapılandırılmış görüşmeler yapılmıştır. Yapılan analizler sonucunda tahmin tanımı, tahmin becerisinin çeşitleri, tahmin becerisi için kullanılan stratejiler, sınıf içi/dışı uygulamalar, tahmin öğretiminde karşılaşılan zorluklar ve tahmin becerisinin öğretim programındaki yeri olmak üzere yedi tema oluşturulmuştur. Elde edilen sonuçlara göre matematik öğretmenleri tahmin becerisinin tanımını tam olarak yapamamakla birlikte, çeşitlerini ve stratejilerini de tam olarak ortaya koyamamaktadır. Öğretmenler bu becerinin günlük yaşamda önemli bir beceri olduğunu söylemelerine rağmen matematik derslerinde bu becerinin öğretimine dair herhangi bir işleniş yapmadıklarını dile getirmektedirler. Bunun altında yatan en önemli sebepler; öğretmenlerin bu becerinin öğretilmesi gerekliliğine inanmadıkları, ülke çapındaki sınavlarda soru olarak öğrencilerin karşısına çıkmayacağını düşünmeleri ve kendilerinin de bu konuda yeterli donanıma sahip olmadıklarını düşünmeleri olarak sıralanabilir.
\end{abstract} Anahtar kelimeler: tahmin, ortaokul matematik öğretmeni, matematik dersi öğretim programı.

\section{Giriş}

Tahmin etme günlük yaşantımızda sıkça karşımıza çıkan matematiksel bir beceridir. Bireyler çoğu zaman farkında olmayarak tahmin becerilerini yaşantılarında kullanırlar. Örneğin alışverişte ödeme miktarını hesaplamada (Rubenstein, 1985), kalabalık bir grubun kaç kişi olduğunu söylemede (Rubenstein,1985) ve ölçme gerektiren durumlarda (Gooya, Leyla, Khosroshahi \& Teppo, 2011; Van de Walle, 2004) tahmin kullanıldı̆̆ı gözlenebilir. Bununla birlikte, orantısal akıl yürütmede de tahmin becerileri dikkate alınmaktadır (Cramer \& Post, 1993). Hatta matematiksel problemlerin çözümlerinde (Milli Eğitim Bakanlığ [MEB], 2009a, 2009b; NCTM, 2000); bir olayın olma ihtimali hakkında karar vermede,

\footnotetext{
† İletişim: Burçak BOZ-YAMAN, Muğla Sitkı Koçman Üniversitesi, Eğitim Fakültesi, Matematik ve Fen Bilimleri Eğitimi Bölümü, Muğla/TÜRKIYYE
} 
öngörüde bulunmada (MEB, 2009a, 2009b; NCTM, 2000) ve varsayımları belirlemede de (MEB, 2009a, 2009b) tahmin becerisi kullanılmaktadır. Matematik derslerinin yanı sıra farklı derslerde de tahmin etme becerisi gözlenmektedir (MEB, 2006; MEB, 2009a, 2009b, 2009c; 2009d; 2013). Bunlara örnek olarak Türkçe dersinde verilen metin içinden kelimenin anlamını belirlemede (MEB, 2009d), İngilizce derslerinde verilen ipuçlarından yararlanarak tahmin etme etkinliklerinde (MEB, 2006), Fen Bilimleri derslerinin geliştirmeyi hedefledikleri bilimsel süreç becerilerinde (MEB, 2009c; Osborne, 2005) kullanıldığı söylenebilir. Ayrıca iktisat, kimya, fizik, biyoloji, madencilik, jeoloji gibi alanlarda ve farklı mesleklerde özellikle matematiksel modelleme yapılırken ve karar verme süreçlerinde tahminler kullanılmaktadır (Lesh, Hoover, Hole, Kelly, \& Post, 2000; Lingefjärd, 2006).

Reys'e (1986) göre tahmin etmek bir konu hakkında karar verebilmek adına net cevaba olabildiğince yakın cevap üretebilme sürecidir. Smart (1982) tahmin kavramı için yaklaşık bir fikir sahibi olmak derken, Thompson (1979) ise tahmin etmenin eğitilmiş öngörü olduğunu belirtir. Alanyazında yapılan tanımlara dayanarak bu çalışmada araştırmacılar tahmin etme kavramını, eldeki verileri esnek ve hızlıca alışagelmemiş zihinsel bir süreçten geçirerek kabul edilebilir bir sonuç elde etmek olarak tanımlamışlardır. Nasıl tahminin tanımları birbirinden farklılık göstermekteyse, aynı farklılık tahmin çeşitlerinin tanımlarında da vardır (Lemaire, Lecacheurve, \& Farioli, 2000; Micklo,1999; Segovia \& Castro, 2009). Örneğin, bazı araştırmacılar tahmini; işlemsel tahmin ve ölçüsel tahmin şeklinde sınıflandırırken (Segovia \& Castro, 2009), bazı araştırmalarda da işlemsel, yığın ve ölçüsel olarak sınıflandırılmaktadır (Hanson \& Hogan, 2000). Bununla beraber ileriye dönük tahmin (MEB, 2009a, 2009b; NCTM, 2000), yeterli veri olmayan durumlarda belirsizliğin cevabının tahmini (MEB, 2009a, 2009b, 2009d) ve problem çözme stratejisi (MEB, 2009a, 2009b; Posamentier \& Krulik, 1998) olarak tahminden söz edilmektedir.

$\operatorname{NCTM}(1989,2000)$ yayınladığı standartları içinde tahmin etmenin öğrencilerin sayıları anlama, onlarla esnek bir şekilde işlem yapabilme ve cevaplarının anlamlılığını tartışma gibi konuları kavrayabilmeleri için önemli bir araç olduğunu belirtmektedir. Bunlara ek olarak yapılan araştırmaların sonuçlarından yararlanarak tahmin becerilerinin faydaları şu şekilde sıralanabilir: Matematik kavramlarını kazandırma (Lemaire, Lecacheur \& Farioli, 2000; Patkin \& Gazit, 2013; Siegler \& Booth, 2005); sayı duyusu/algısını geliştirme (Carroll,1996); öğrencilerin ölçme ile ilgili anlamalarını değerlendirme (Gooya et al., 2011); matematiksel ilişkilerin genel olarak anlaşılmasını sağlama (Dowker, 1992); bilgiyi yapılandırma (Osborne, 
2005); becerileri gerçek yaşamda kullanma (Siegel, Goldsmith, \& Madson, 1982); bilişüstü becerileri ilerletme (Carroll, 1996); öğrencilerin motivasyonunun artmasına ve standart olan birimlere alışmalarına yardım etme (Van de Walle, 2004); tahmin stratejilerini paylaşımının öğrencilerin farklı düşünme biçimlerini anlamalarına olanak sağlaması ve sınıfta zengin bir tartışma ortamı sunma (NCTM, 2000); kağıt-kalem hesaplama veya hesap makinesi ile elde edilen cevabın kabul edilebilirliğine dair karar verilmesi (Bestgen, Reys, Rybolt, \& Wyatt, 1980) ve matematiğin içinde risk almayı öğretmesi, böylece çocukların değişik stratejileri uygulama konusunda esneklik kazanması, bunun da öğrencileri yeni yollar bulmaya isteklendirmesi (Adams, Onslow, Edmunds, Chapple, \& Waters, 2005) şeklinde sayılabilir.

Tahmin çeşitlerinin ve stratejilerinin kullanıma dair farklı yaş gruplarında hem ulusal hem de uluslararası alanda bilimsel çalışmalara rastlanmaktadır (Boz, 2004; Çilingir \& Türnüklü, 2009; Gooya, Leyla, Khosroshahi, \&Teppo, 2011; Kılıç \& Olkun, 2013; Lemaire, Lecacheur \& Farioli,2000; Levine, 1982; Reys, Rybolt, Bestgen, \& Wyatt, 1982; Siegler \& Booth, 2004; Sullivan, Juhasz, Slattery, \& Barth, 2011; Toluk-Uçar \& Aytekin, 2014). Bu araştırmalara göre işlemsel tahmin stratejileri birbirinden farklılıklar gösterebilmektedir ancak en yaygın olarak kullanılan stratejiler Reys, Rybolt, Bestgen ve Wyatt (1982) tarafindan yapılan araştırmada ortaya koyulmuş olan işlemdeki sayıları değiştirme (reformulation), işlemleri değiştirme (translation) ve çıkan sonucun yaklaşıklığını sağlamak için düzenlemeler yapma (compensation) olarak üç şekilde sınıflandırılmıştır. Diğer yandan Lemaire, Lecacheur ve Farioli (2000) işlemsel tahmin stratejilerini yuvarlama, geriye doğru yuvarlama (truncation), çıkan sonuçta yaklaşıklığı sağlamak için düzenlemeler yapma olarak gruplandırmıştır. Levine (1982) ise kesir ifadesine dönüştürme, bir sayının 10’nun kuvvetleri ile çarpımı, bir sayıyı 10'nun kuvvetleri şekline dönüştürme, her iki sayıyı yuvarlama, bir sayıyı yuvarlama; bilinen sayıları kullanma; işlemleri ve sayıları dönüştürme; algoritmik işlemler uygulayarak ve bu işlemleri birleştirme şeklinde isimler kullanarak birçok strateji ortaya koymuştur. Bu tarz isimlendirmeye matematik dersi öğretim programlarından ilk olarak 2009 y1lı öğretim programında yer verilmiştir (MEB, 2009a, 2009b). Bu öğretim programında yuvarlama stratejisinde sayılar işlem yapmayı kolaylaştıracak şekilde belirli kurallar uygulanmadan uygun sayıya dönüştürme şeklinde ele alınmıştır. 2009 yılı ilköğretim matematik dersi öğretimi programında tahmin öğretiminde yuvarlama, gruplandırma, uyuşan sayıları kullanma, ilk veya son basamakları kullanma, dağılma stratejilerinin uygulanması beklenmektedir (MEB, 2009a, 2009b). Daha sonra takip eden 2013 programında da benzer isimlendirmeler kullanılmıştır (MEB, 2013). 
İşlemsel tahminin yanı sıra, ölçüsel tahmin stratejileri de kendi içinde farklılık göstermektedir. Örneğin, Gooya, Leyla, Khosroshahi ve Teppo (2011) sabit nokta ya da referans noktası kullanma, birim tekrarı, karşılaştırma, zihinsel metre, önceki bilgiyi kullanma ve sıkıştırma stratejileri şeklinde stratejiler tespit etmiştir. Çilingir ve Türnüklü’nün (2009) isimlendirdiği stratejiler ise gözünde canlandırma, parçadan bütüne ulaşma, karşılaştırma, deney yoluyla tahminde bulunma, rastgele ve var olan bilgi ve tecrübelere dayalı tahmin etme olarak sayılabilir. MEB'in (2009a, 2009b) matematik dersi öğretim program kitapları incelendiğinde sadece referans stratejisinden söz edildiği görülmektedir. Ancak öğretim programlarında stratejinin adının verilmemesine rağmen birçok stratejinin kullanıldığı da görülmektedir. Örneğin 2009 y1lı ilköğretim matematik dersi öğretim programlarındaki örnekler incelendiğinde bu stratejinin sabit nokta ya da referans noktası kullanma, birim tekrarlama stratejisi, önceki bilgiyi kullanma, zihinsel metre, karşılaştırma, parçalamayığınlama, sıkıştırma stratejilerini de kapsadığı görülmektedir. Ayrıca bu öğretim programında hem işlemsel hem de ölçüsel tahmin sonucunda elde edilen gerçek değerler tahmin sonucu olarak kabul edilmektedir.

Reys'e (1986) göre günlük yaşamdaki matematik uygulamalarının \%80’i net cevaplı sayısal sonuçlardan çok; tahmini, yaklaşık cevaplar olarak elde edilmektedir. Bu çeşitlilik ve sıklıkta kullanılan tahmin becerisi, matematik dersi içerisinde önemli bir yere sahip olup; Türkiye, Amerika Birleşik Devletleri, Malezya, Japonya, Çin gibi bazı ülkelerin matematik dersi öğretim programlarında kazandırılması hedeflenen beceriler arasında sayılmaktadır (Alajmi, 2009; Liu, 2009; MEB, 2009a, 2009b, 2013; Mohamed \& Johnny, 2010; NCTM, 2000; Reys, Reys, Nohda, Ishida, Yoshikawa, \& Shimizu, 1991). Ülkemizde 1948 y1lından bu yana incelenen ilköğretim ile ilgili matematik dersi öğretimi programlarında bu beceriye önem verildiği görülmektedir (MEB, 1948, 1968, 1998, 2009a, 2009b, 2013, 2015; MEGSB, 1983). Ancak özellikle 2005 ve sonrası yı1larda yürürlüğe giren ilköğretim matematik dersi öğretimi programlarında farklı tahmin çeşitlerine yönelik beceriler daha çok ön plana çıkmıştır. Bunun gerekçelerinden biri olarak son yıllardaki öğretim programlarının beceri odaklı olması gösterilebilmektedir.

İlköğretim matematik dersi programlarının tahmin becerisine dair içeriklerine bakıldığında, 1968-2015 yıllarında uygulanan bu programlarda farklı sayılarda tahmine yönelik amaç ve/veya hedefler bulunmaktadır. Ancak "tahmin" sözcügünün bulunduğu hedef ifadeleri daha çok 1-5. sınıflarda yer verilirken 6-8' de daha çok problem çözme becerisinin içerisinde tahmine yer verilmiştir. Veriye dayalı tahmin becerisi ise 1983, 1998, 2009 ve 2013 
öğretim programlarında yer alırken olasılıkla ilgili olan tahmin sadece 2009 yılında vardır. En yoğun şekilde ve farklı öğrenme alanlarında tahmin kazanımlarına sahip olan öğretim programı 2009 y1lına ait 1-8. sinıflar matematik derslerine aittir.

Programlarda yer alan işlemsel tahmin, başta toplama ve çıkarma olmak üzere diğer işlemleri kapsamaktadır. Bazı öğretim programlarında "tahmin" ifadesi açık olarak yazılmasa da problem çözme adımlarından biri veya stratejilerinden biri olarak yer almaktadır. Farklı seviyelerdeki öğretim programlarından farklı öğrenme alanlarının amaç veya hedeflerine dair örnekler verilebilir. Bunlar "İşlemlerde ve hesaplamalarda sonuçların önceden tahmin yoluyla ve yazılanlarda ayrıca sağlama ile sonuçların doğru olup olmadığını muhakeme etme alışkanlığını geliştirmek." (MEB, 1968, s.140), "Dört basamaklı doğal sayılar içinde kalacak şekilde; bu sınıfın hedefleri arasında yer alan ölçüler ile ölçü birimleri ve en çok işlem kullanılarak çözülebilecek bir problemin sonucunu tahmin edip söyleme veya yazma (Milli Eğitim Gençlik ve Spor Bakanlığı (MEGSB), 1983, s.175); bir bölme işlemini yapmadan, bölümünü tahmin edip söyleme (MEB, 1998, s.233); ondalık kesirlerle yapılan işlemlerin sonucunu strateji kullanarak tahmin eder (MEB, 2009b, s.149) ve tam kare olmayan sayıların kareköklerini strateji kullanarak tahmin eder (MEB, 2013, s.299)" şeklindedir.

Ölçüsel tahmin ise ağırlıklı olarak uzunluk ölçme olmak üzere kütle, alan ve hacmi içermektedir. Bu konulara dair örnekler: "Uzaklık ve ağırlık tahminleri yapmak ve ölçerek kontrol etmek (MEB, 1968, s.138); belirtilen bir uzunluğu, metre veya santimetre cinsinden tahmin etme (MEB, 1998, s.289); açıların ölçülerini tahmin eder ve tahminini açıyı ölçerek kontrol eder (MEB, 2009a, s.230); dik dairesel silindirin hacmini tahmin etmeye yönelik çalışmalara yer verilir (MEB, 2013, s.41) ve verilen bir çokluktaki nesne sayısını tahmin eder; tahminini sayarak kontrol eder (MEB, 2015, s.22)" şeklindedir.

Bazı öğretim programlarında olasılık ve istatistik öğrenme alanı ile ilgili tahmin kazanımlarına da yer verilmiştir. Bunlara ait örnek alıntılar; "Bir şekil, sütun, daire veya çizgi grafiğinden, belirtilen konuda geleceğe ait tahminde bulunup tahmini söyleme veya yazma (MEGSB, 1983, s.331); verilen bir çizgi grafiğinde belirtilen konuda geleceğe ait tahminde bulunup tahmini söyleme (MEB, 1998, s.241); verilere dayalı olarak tahminler yürütür (MEB, 2009b, s.272); olayların olma olasılığı ile ilgili tahminler yapar (hava tahmini, ekonomik tahminler, olayların olma olasılıkları vb. ile ilgili gazete kupürleri incelenerek tahminler yaptırılıp kontrol ettirilebilir) (MEB, 2009a, s.319)" olarak verilebilir.

Yukarıda alıntıları ile birlikte verilen kazanım, hedef/davranışlar ve amaçlar ülkemiz tarihinde 1968 'den bu yana bulunan tüm programlarda tahmin etme becerisinin önemle 
vurgulandığını göstermektedir. Öğretmenlerin sınıf içi uygulamalarının temel kaynağı öğretim programlarıdır. Her ne kadar yazılı öğretim programlarının yanı sıra sınıflarda örtük programların uygulandığı bilinse de bir öğretmenin öğretim programları hakkındaki bilgisi Shulman'dan (1986) bu yana öğretmenlik alan bilgisi içerisinde sayılmaktadır. Bu nedenle öğretmenlerin öğretim programlarında yer alan kavramlardan haberdar olmaları ve bu kavramları öğretim ortamlarına yansıtmaları gerekmektedir. Günümüze kadar olan matematik dersi ögretim programlarının hedef/davranış ya da kazanımlarında, genel ve özel hedeflerinde tahmin etmeye dair uygulamalara yer verildiği görülmektedir. Bu durum 1968'den bu yana öğretmenlerin de sinıflarında bu önemi ortaya koyan uygulamalar yapmasını gerektirmektedir. $\mathrm{Bu}$ nedenle öğretmenlerin öğretim programından ve içeriğinden haberdar olma durumları, ilgili konuya dair tutum ve düşünceleri ile konuya dair öğrenme ortamlarını kendi bakış açıları bağlamında oluşturmaları incelemeye değer bir husustur. Zira öğretmenlerin olumlu tutumlarının bir dersi öğrenmede önemli bir faktör olduğunu ortaya koyan çalışmalar bulunmaktadır (Fang, 1996; Ford 1994; Kagan, 1992; Raymond, 1997; Thompson, 1992). Bu nedenle öğretmenlerin bu beceriye ve öğretimine dair neler düşündüğü bu becerinin etkili bir şekilde öğretilmesinde önemli bir ilk adımdır. Tahmin becerisinin ne derece öğretildiği, öğrencilerin ne kadar başarılı olduğu ve bu becerinin çeşitleri ve stratejileri üzerine birçok çalışma yapılmasına karşın, öğretmenlerin bu hususta düşüncelerini inceleyen pek fazla çalışma bulunmamaktadır (Tsao \& Pan, 2013).

Alanyazında tahmin becerisine dair yapılan araştırmalar incelendiğinde farklı yaş gruplarında tahmin konusunda sorunlar yaşandığı, bu becerinin yeterli derecede edinilemediği ya da bu becerinin kullanımında başarısızlıklar yaşandığı belirlenmiştir (Hanson \& Hogan, 2000; Lemaire \& Lecacheur 2002; Siegler \& Booth 2004; Verschaffel, Greer, \& De Corte, 2007). Bu başarısızlıkların nedenleri arasında öğretmenlerin yeterlikleri de yer almaktadır. (Alajmi \& Reys, 2007). Ancak literatüre bakıldığında öğretmenler ve öğretmen adaylarıyla tahmine yönelik çalışmalar yapıldığı görülmekle birlikte (Alajmi, 2009; Bestgen, Reys, Rybolt, \& Wyatt, 1980; Gliner,1991; Goodman, 1991; Tirosh \& Graeber, 1989), bu çalışmalar çoğunlukla öğretmenlerin ya da öğretmen adaylarının tahmin etmedeki başarılarının tespiti ya da kullandıkları stratejilerin belirlenmesi doğrultusundadır.

Sonuç olarak tahmin becerisi bireyin okul yaşantısında, günlük hayatında, mesleklerinde ve farklı disiplinlerde önemli bir yere sahiptir. Ne yazık ki bu beceri ilköğretim matematik dersi öğretim programlarında gerek kazanım ve hedef/davranışlar gerek bir beceri olarak her zaman yer almasına karşın, öğrenci başarısına dair yapılan çalışmalarda bu 
becerinin bireylerde zayıf olduğu ve buna bağlı olarak da başarının düşük olduğu tespit edilmiştir (Boz, 2004; Çilingir \& Türnüklü, 2009; Toluk-Uçar \& Aytekin, 2014). Bu düşük başarının birçok nedeni olabileceği gibi ders içerisinde matematik öğretmenlerinin bu konu ve beceriye dair tutumları, düşünceleri ve oluşturdukları öğrenme ortamlarının da etkili olduğu söylenebilir. Özellikle matematik öğretmenlerinin öğrettikleri konuya olan tutum, beceri ve inanışlarının öğrencilerin matematik başarıları üzerinde etkili olduğu göz önünde bulundurulursa, tahmin becerisine dair öğretmenlerin tutum ve inanışlarının da incelenmesi gerekliliği ortaya çıkmaktadır.

$\mathrm{Bu}$ nedenle, bu çalışmada farklı sürelerde mesleki deneyime sahip olan ortaokul matematik öğretmenlerinin tahmin ile ilgili görüşleri ve düşünceleri incelenmek istenmiştir. $\mathrm{Bu}$ amaca yönelik olarak araştırmanın temel problemi "Farklı yıllara ait matematik dersi öğretim programlarında öğretmenlik yapan ortaokul matematik öğretmenlerinin tahmin becerisine ve bu becerinin sınıf içinde kullanımına dair görüşleri nelerdir?” olarak ortaya koyulmuştur. Matematik öğretmenlerine dair yapılan incelemede farklı öğretim programlarına 1968 yılındaki matematik dersi öğretim programı ile başlanmıştır çünkü ulaşılan katılımcı öğretmenlerden en fazla deneyime sahip olan öğretmen ancak bu öğretim programında çalışmıştır.

\section{Yöntem}

Araştırmada nitel araştırma yöntemlerinden olgu bilim (fenomoloji) deseni kullanılmıştır. Olgu bilim araştırmalarında bireylerin belli bir olay, konu, olgu ya da kavrama yükledikleri anlamı ortaya koymak ve derinlemesine incelemek amaçlanmaktadır (Creswell, 2008). Bu araştırmanın incelenen olgusu ise matematik dersi öğretim programlarına yer alan tahmin becerisi kavramıdır. Bu araştırmada tahmin becerisi olgusunu ortaokul matematik öğretmenlerinin nasıl algıladığı ve derslerinde bu kavramı öğretmeye dair neler düşündükleri betimlenmiştir. Olgu bilim deseninde araştırmacı, incelenen olguya dair deneyimleri ve bu deneyimlerin meydana geldiği ortamı ve koşulları incelemeyi hedefler (Creswell, 2013). Dolayısı ile matematik öğretmenlerinin tahmin becerisini farklı öğretim programları sürecinde yıllar içerisinde değişen öğretim ortamlarında nasıl sundukları ve bu kavrama yükledikleri anlamları incelemek, bu araştırmanın odak noktasını oluşturmaktadır. 
Katılımcllar ve Veri Toplama Süreci

Araştırmaya yedi ortaokul matematik öğretmeni katılmıştır. Katılımcıların belirlenmesindeki ölçüt, öğretmenlerin Milli Eğitim Bakanlığınca yürürlükte olan matematik dersi öğretim programlarından olabildiğince fazla sayıda öğretim programında öğretmenlik yapmış olmalarıdır. Bu nedenle araştırmada amaçlı örnekleme yöntemi temel alınmıştır (Yıldırım ve Şimşek, 2003). Bu çerçevede 1968 yılı matematik dersi öğretim programlarından itibaren öğretmenlik yapan üç öğretmen ile devamındaki öğretim programlarında öğretmenlik yapan dört öğretmen olmak üzere toplamda yedi öğretmene ulaşılmıştır.

Katılımcılar 1968-2013 yılları arasında kullanılan öğretim programlarında öğretmenlik yapmış olması, mezun oldukları okul ve öğretmenlik yaptıkları yerler itibari ile birbirlerinden oldukça farklı ve çeşitlilik ilkesini yansıtacak özelliklere sahiptirler. Katılımcılara dair bazı özellikler Tablo 1'de özetlenmiştir. Öğretmenlerin isimlerinin yerine her bir öğretmene bir numara verilerek birinci öğretmeni temsilen Ö1 gibi kısaltmalar kullanılmıştır.

Tablo 1

Katılımclların Demografik Özellikleri

\begin{tabular}{|c|c|c|c|c|c|c|}
\hline Öğretmen & Cinsiyeti & $\begin{array}{c}\text { Mezuniyet } \\
\text { Yılı }\end{array}$ & Okulu & Hizmet Yılı & $\begin{array}{l}\text { Çalışma } \\
\text { Durumu }\end{array}$ & $\begin{array}{c}\text { Çalıştığı } \\
\text { Öğretim } \\
\text { Programı }\end{array}$ \\
\hline$\ddot{O} 1$ & Erkek & 1974 & Eğitim Enstitüsü & 33 MEB; 7 y1l dershane & Emekli & $1968-2013$ \\
\hline$\ddot{O} 2$ & Erkek & 1965 & Eğitim Enstitüsü & 32 y1 MEB & Emekli & $1968-1990$ \\
\hline$\ddot{3} 3$ & Erkek & 1972 & Eğitim Enstitüsü & 43 y1l MEB & Çalışıyor & $1968-2013$ \\
\hline$\ddot{O} 4$ & Kadın & 1985 & Eğitim Fakültesi & 30 y1l MEB & Çalışıyor & $1983-2013$ \\
\hline$\ddot{O} 5$ & Kadın & 2004 & Eğitim Fakültesi & 7 y1l MEB; 4 y1l dershane & Çalışıyor & $2009-2013$ \\
\hline$\ddot{06}$ & Kadın & 2000 & Fen Fakültesi & 10 yıl MEB; 5 yıl dershane & Çalışıyor & $1998-2013$ \\
\hline$\ddot{0} 7$ & Erkek & 2004 & Eğitim Fakültesi & 7 y1l MEB; 4 y1l dershane & Çalışıyor & $2009-2013$ \\
\hline
\end{tabular}

Hizmet yılı 11 ile 43 yıl (verinin toplandığı yıl olan 2015 yılına göre) arasında değişen ve bahsi geçen öğretim programlarında öğretmenlik yapmış yedi matematik öğretmeni ile yarı yapılandırılmış görüşmeler yapılmıştır. Yarı yapılandırılmış görüşme soruları, araştırmacıların yaptığı kayıt dışı görüşmelerden elde edilen veriler doğrultusunda hazırlanmıştır. Görüşme soruları önceden belirlenen temalar altında toplanmıştır. Miles ve Huberman'ın (1994) da belirttiği üzere araştırmada kullanılan sorular gerek kuramsal çerçeveden önce gerek paralel olarak oluşturulabilmektedir. Buna dayanarak araştırmada görüşme soruları önceden hazırlanan tematik çerçeveye dayanarak oluşturulmuştur ancak görüşme esnasında verilen cevapları takip eden yeni sorular da eklenmiş ve yeni temaların oluşmasına sebep olmuştur. Örneğin, öğretmenlere tahmin öğretirken sınıf içinde ya da dışında kullandıkları yöntemleri 
sorduğumuz soruda bu becerinin öğretiminde sıkıntılar olduğunu, bunun da altında yatan sebebin aslında öğretmenlerin bu beceriye yeteri kadar inanmadığını belirtmeleri üzerine temalar arasına “öğretimde karşılaşılan zorluklar” başlığı da eklenmiştir.

Araştırmacılar tarafından hazırlanan yarı yapılandırılmış görüşme formu (Ek 1) içerik geçerliğini sağlamak adına Balcı'nın (2006) da belirttiği üzere alanda uzman kişiler tarafından incelenmiştir. Matematik öğretimi alanında uzman bir akademisyen ile ortaokulda görev yapan bir matematik öğretmeni tarafindan değerlendirilen görüşme formu verilen dönütler doğrultusunda yeniden düzenlenmiştir. Verilen dönütlerden bir tanesi ölçüsel tahmine dair örnekler verilerek soruların yeniden sorulması üzerine olmuştur. Katılımcı öğretmenlerin her biriyle 30-40 dakika süren yarı yapılandırılmış görüşme yapılmış, bu görüşmeler ses kayıt cihazı ile kaydedilmiştir. Her görüşme farklı bir mekanda katılımcıların istekleri değerlendirilerek gerçekleştirilmiştir.

\section{Veri analizi}

Araştırmada veriler içerik analizi yöntemi ile analiz edilmiştir. İçerik analizi dokümanlardaki; bu araştırma için görüşmelerin deşifre metninde; yer alan ilişkili söz veya söz öbeklerini belirlemek amacıyla kullanılmaktadır (Yıldırım ve Şimşek, 2006). Verilerin kodlanması aşamasında araştırmacılar, yedi öğretmenden bir tanesi ile yapılan görüşmenin deşifre metnini ayrı ayrı birkaç kez dikkatlice okuyup inceleyerek, ilgili konuya dair öğretmenlerin görüş ve düşüncelerini anlamlı bölümlere ayırmaya ve her yazılan bölümün kavramsal olarak ne anlam ifade ettiğini bulmaya çalışmışlardır. Birbiriyle anlamlı bulunan kısımlar kodlanmıştır. Bağımsız yapılan tema ve kod oluşturma aşamasından sonra araştırmacılar belirledikleri kodları kullanarak, kodlayıcılar arası güvenirliliği "Görüş birliği/(Görüş birliği + Görüş ayrılığı) X 100" formülünü (Miles ve Huberman, 1994) kullanarak hesaplamışlardır. Buna göre kodlayıcılar arası güvenirlik \%85 olarak tespit etmiştir. Farklı kodlanan veriler üzerinde tekrar bir çalışma yapılarak, uyum arttırılmış ve tam (\%100) bir uyum sağlanmıştır. Araştırmacılar tarafından görüşme soruları temel alınarak oluşturulan ve devamında görüşme esnasında ortaya çıkan yeni kodlar ve temaların meydana getirdiği liste Tablo 2'de verilmiştir. 
Tablo 2

Görüşmelere dair Tema ve Kodlar

\begin{tabular}{ll}
\hline Tema & \multicolumn{1}{c}{ Kod } \\
\hline 1. Öğretmenlerin Tahmin Tanımlamaları & $\begin{array}{l}\text { Yaklaşık, yuvarlak, aşağı-yukarı, zihinden işlem sonucunu } \\
\text { kestirmek } \\
\text { Ölçüsel tahmin, işlemsel tahmin, geleceğe yönelik öngörü, } \\
\text { problem çözmede tahmin }\end{array}$ \\
2. Tahmin Çeşitleri & Yuvarlama, uyumlu sayıları kullanma, referans noktası \\
3. Kullanılan Stratejiler & Yuvarlama çalışması, yaklaşık sonuç buldurma, yaklaşık \\
4. Sinıf içi/dışı öğretmen & uzunluk ölçümleri yapma \\
Uygulamaları & $\begin{array}{l}\text { Günlük yaşam becerisi, gereksiz görülmesi, sınavda } \\
\text { çımaması }\end{array}$ \\
5. Tahmin Becerisinin Önemine & İnanmamak, temel aritmetik bilgisi, öğretim \\
Dair Görüşleri & programlarının yoğunluğu \\
6. Tahmin Öğretiminde Karşılaşılan & Uygulanmayan kurallar, ders kitabı \\
Zorluklar & \\
7. Öğretmenlerin Öğretim & \\
Programlarındaki Tahmine Dair Görüşleri & \\
\hline
\end{tabular}

\section{Bulgular ve Yorumlar}

Bu bölümünde Tablo 2'de verilen yedi tema alt başliklar altında sunulmuştur. Bulgular ortaokul matematik öğretmenleri ile yapılan yarı yapılandırılmış görüşmelerden doğrudan yapılan alıntılar ile desteklenmiştir.

\section{Öğretmenlerin Tahmin Tanımlamaları}

Tahmin becerisinin tanımı konusunda katılımcılar standart bir yaklaşımdan daha çok tahminin pratik kullanım alanlarını ön plana çıkaran, sezgilere dayalı tanımlamaları tercih etmişlerdir. Öğretmenlerin görüşmelerde sıklıkla kullandığı tahmin etme tanımlarında "yaklaşık, yuvarlak, aşağı-yukarı, zihinden işlem sonucu kestirmek" gibi ifadeler yer almaktadır. Bazı öğretmenler tahmin becerisi tanımında sadece işlemsel tahmin becerisini düşünerek tanım yapmışlardır. Örneğin; 1968 programından günümüze tüm öğretim programlarında öğretmenlik yapmış olan Ö1'in verdiği cevap şöyledir: "Sayılarla kullanılan tahminde, gerçek cevaplara yakın sonuçlar bulunur. Yani üç aşağı beş yukarl dediğimiz kavramın karşılı̆̆ıdır tahmin.” 1983 programı ile öğretmenlik yıllarına başlayan Ö4 tahminini "yaklaşık değer" olarak tanımlamıştır: "Net bir cevaba yaklaşık değerlerle yaklaşmak. Diyelim ki iki sayıyı çarpımı 1330 çıkacak, 1330’u yaklaşık sayıda 1300 bulmam, yani hesap yapıp da bulmam değil." Mesleki hizmet yılları 11 y1l olan Ö5 ve Ö7, tahmin becerisinin oldukça fazla vurgulandığı 2009 programı ile öğretmenliğe başlamışlardır. Bu öğretmenler tahmin etmenin tanımı için sırasıyla "sayıların yuvarlama yapılarak yaklaşık sonuçların 
bulunmasıdır." ve "bir konu hakkında sonucu kestirebilmek" şeklinde yorum yapmışlardır. Buna ek olarak iki öğretmen de ölçüsel tahmin tanımına dair sadece örnekler vererek açıklama yapmışlar. Ö1 “çocuğun önüne gelen bir nesneyi doğru ya da yakın bir biçimde algılayabilmesi...yani mesela pazardan aldı̆̆ı şeyin ă̆ırlı̆̆ının $1,5 \mathrm{~kg}$ gelip gelmediğini algılayabilmeli" olarak ifade ederken, Ö6 ise ölçüsel tahmin için "ölçmede mesela uzaklıkta tahmin edebilir. Mesela sıranızın boyunu ve enini tahmin edin diyorum" örneği ile tanım vermeye çalışmıştır.

Bazıları da sadece ölçüsel tahmin becerisini temel alarak tanım yapmışlardır. Örneğin, 1968-1990 yılları içerisinde yer alan 3 farklı matematik dersi öğretim programında görev yapan Ö2 ise aşağıdaki şekilde ölçüsel tahmin becerisine dair bir yorum yapmayı tercih etmiştir:

Tahmin etmek demek ölçülerle ilgili bir şeydir. Mesela, şu işi kaç dakikada yaparsın ya da şu yolu ne zamanda gidersin, şu kaç kg, şu kaç litredir ya da şu ne kadar uzun gibi. Ama bunu bilmesi için [öğrencinin] bazı birimleri bilmesi gerek. Litreyi gözünde canlandıracak. Şu[bardağı işaret ederek] kaç litre demesi için litreyi ve alt üst katlarını bilmesi gerekir.

Öğretmenin yorumlarından bu örnek durumları sadece "ölçüsel tahmin nedir" sorusuna cevap vermek için kullandığı ancak bu tarz bir uygulamayı ve öğrenme etkinliğini sınıfında yaptırıp yaptırmadığı sorgulandığında "hayır" diyerek cevaplandırılmıştır.

Tahmin nedir sorgulamasında sık sık zihinden işlem yapma ile karıştırılan cevaplar da gelmiştir. Örneğin mesleğinde 43. yılını yaşayan ve 1968 'den bu yana bütün matematik dersi öğretim programlarında çalışmış olan Ö3 “Sonucu kısa yoldan bulmaya denir. Yuvarlama kullanirsin mesela. Ya da bazen kisa yoldan hemen hesaplarsın, kestirme yollar kullanirsin. Mesela 10 ile çarp 2'ye böl, 5 ile çarpmış olursun" şeklinde yaptığı açıklamada tahmin etme ile zihinden işlem yapmayı karıştırarak, birbirinin yerine geçecek şekilde tanımlamıştır. Ö3 tahmin etmenin diğer alanlardaki uygulamalarını göz ardı ederek sadece işlemsel tahmin ve zihinden hesaplamaya odaklanmıştır. 15 yıllık öğretmenlik deneyimi olan Ö6 da tahmin becerisini tanımlarken "bir problemin sonucunda tam işlem yapmadan sayıları yuvarlayarak bulmaya çalışmaktır yani belki kafadan yaklaşık sonucu tahmin edebiliriz bu yani." ifadelerini kullanmıştır. Ancak bununla beraber tanımın devamında yaptığı açıklamalarda şöyle devam etmiştir; "Zihinden işlem yapmak gibi aslında. 5 ile çarpma yerine 10 ile çarpıp 2'ye bölme yaparak pratik olarak cevabı bulmak da olabilir." Bu cevabı ile Ö3'ün verdiği örneğin aynısını kullanmış olması dikkat çekicidir. $\mathrm{Bu}$ benzer yorumlar tahmin etme ile zihinden 
işlem yapmanın sık sık karıştırıldığına ve bu durumun hem 43 yıllık hem de 15 yıllık öğretmen için geçerli olduğuna dair birer örnek olabilir.

Genel olarak, katılımc1lara sorulan "Tahmin ne demektir?" sorusuna verilen cevaplar işlemsel ve ölçüsel tahmin kavramları çerçevesinde verilmiştir. Bu cevapların ortak noktaları ise "yaklaşık", "yuvarlama"," aşağı-yukarı" gibi kelimelerin sıklıkla kullanılması ve tahmin sonucunun kesin veya net cevap olarak düşünülmemesidir.

\section{Tahmin Çeşitleri}

Tahminin çeşitleri konusunda da öğretmenler birbirinden farklı yorumlar yapmışlardır. Görüşme deşifrelerinde yapılan kodlamalar arasında "ölçüsel tahmin, işlemsel tahmin, geleceğe yönelik öngörü, problem çözmede tahmin" şeklinde ifadeler kullanılmıştır. Ö1, Ö2 ve Ö3 dışında diğer öğretmenler tahmin etme becerisi denildiğinde öncelikle sayıların yuvarlaması ile ilgili yorumlar yaparak bu becerinin yaklaşık işlemler yapmada kullanıldığını söylemişlerdir. Bu öğretmenlere (Ö4, Ö5, Ö6, Ö7) “Daha farklı çeşitleri var mıdır?” gibi devam soruları sorulduğunda ise bazıları ölçüsel tahminlerin de olduğunu söylemiş̧, bazıları da günlük yaşamda tahmin etmenin yer aldığını (Ö5, Ö6 ve Ö7) ancak öğretim programlarında yer almadığını öne sürdürmüşlerdir. Burada anlatmak istedikleri işlemsel tahmin dışındaki tahmin becerileridir. Ancak ilerleyen görüşme sürecinde her bir öğretmen aslında farkında olmayarak ölçüsel ve diğer alanlardaki tahminlere dair de yorumlar yapmıştır. Sorulara verdikleri çelişkili cevaplar nedeniyle öğretmenlerin öğrettikleri kavramların kavramsal olarak içeriği hakkında yeteri kadar donanımlı olmadığı gözlenmektedir. Ö1, Ö2 ve Ö3 ise işlemsel tahmin başta olmak üzere ölçüsel tahmin, problem çözmede strateji olarak kullanılan tahmin becerileri ve çıkarımda bulunmalar gibi tahmin etmenin farklı yönlerini ve çeşitlerini de kapsayan yorumlar yapmışlardır.

Buna ek olarak, bazı farklı yaklaşımlar da gözlemlenmiştir. Örneğin, Ö6 tahmin etme becerisinin akıl yürütme becerisiyle bağlantısına vurgu yaparak "mesela tahmin etmeyi problemlerde de kullanabilirler. Şimdi yaş problemlerinde annenin yaşının çocuklardan küçük çıkmayacağını düşünmesi ve tahmin etmesi gerekir" yorumunu yaparken devamında sorulan "peki problem çözme sürecinde başka nerelerde kullanılabilir?” sorusuna da

problemi çözerken kullandığı yolun işe yaramadığını görüp başka yollar ararken de tahmin kullanabilir ya da sonucun çıkması gereken aralığı tahmin edebilir yani seçenekler arasında sonuç olarak ele alınamayacak cevapları elimine edebilir.

şeklinde açıklama yapmıştır. Bu cevabı ile Ö6, problem çözme aşamasında stratejilerin seçilmesi sürecinde ya da sonucun tahmin edilmesine yönelik olarak kullanılan tahmin 
çeşitlerini dile getirmiştir. Ö6 öğretmenliğe başladığı program olan 1998 matematik dersi öğretim programından günümüzdeki programlara kadar tahminin problem çözme aşamalarında kullanıldığını vurgulamıştır.

Benzer şekilde Ö1 de “farklı tahmin çeşitleri nelerdir?” sorusuna günlük yaşamdaki matematiksel akıl yürütme becerileri gerektiren durumlara işaret etmiştir. Ö1, bu durum için annesi ile ilgili bir anısını anlatarak örnek göstermiş̧tir;

Pazar masraflarını görmek için babamdan aldığı paranın o haftaki Pazar giderlerine yetip yetmeyeceğini anlardı. Evdeki erzak eksiği ve hafta sonuna kadar azalacak olan miktara dair tahminde bulunarak erzakların yaklaşık fiyatlarını hesaplar ve babamdan daha fazla para istediği ya da fazla parayı geri verdiği zamanlar olurdu.

Ö1 ve Ö6’nın yorumlarına bakıldığında alanyazında da açıklanan tahmin etme becerisinin diğer çeşitlerine (bir olayın olma ihtimali hakkında karar vermede, varsayımları belirleme ve ileriye dönük öngörüde bulunma, vb.) dair cevaplar verdiği görülmektedir. Ö1'in verdiği örnek ise çarpıcıdır;

yani basit şeyleri tahmin edemeyenler kendi hayatları ile ilgili durumlarda nasıl hayati karar alabilirler ki.

Gelecekle ilgili mesela evlilik de bir tahmindir. Yani karşındaki insana dair davranışlarından, yaşamından yorum yaparsin.

Genel olarak öğretmenlerin tahmin çeşitlerini birkaç ana başlık altında topladığ söylenebilir. Sayılarda tahmin en sık verilen örnek olurken, ölçüsel tahmin ve günlük yaşamda akıl yürütme becerisine dair kullanılan tahmin becerileri diğer çeşitleri arasında yer almaktadır. Buna ek olarak problem çözme stratejisi olarak tahminin kullanılması ve günlük yaşamda olasılık durumlarını tahmin etme süreci de tahmin çeşitleri olarak belirtilen durumlardir.

\section{Kullanılan Stratejiler}

Tahmin becerisinde kullanılan stratejilere dair görüşmelerde ortaya çıkan ifadeler arasında "yuvarlama, uyumlu sayıları kullanma, referans noktası kullanma" kodları yer almaktadır. Tahmin etmek denildiğinde ölçüsel tahmini temel alan Ö3 kullandığı stratejinin adını doğrudan söyleyemese de verdiği örneklerden "referans alma stratejisi” kullandığı belirlenmiştir. $\mathrm{Bu}$ durumu şu ifadeler ile anlatmaktadır: "Ölçme için de masanın genişliğini ölçtürüyoruz karışlarla, sonra kaç cm gelir diye soruyorum.”. Buradan da anlaşılacağı gibi, öncelikle sırasının uzunluğunu karışı temel alarak ölçtürdüğü sonra da bunun standart ölçme birimlerine çevrildiği görülmektedir. 
Benzer şekilde Ö2 her ne kadar tahmin etmenin matematikte yeri olmadığını savunsa da ölçüsel tahmin ile ilgili neler yapılırdı diye sorulduğunda; bu beceriyi günlük yaşamında kullanabilmesi için “metreyi ve alt-üst katlarını bilmesi gerekir çocuğun. Ona göre sorulan uzunluğu kafasında canlandırabilsin bunları temel alarak” şeklinde cevaplamıştır. Buradan referans alma stratejisini kullandığı görülmektedir.

Hizmet y1lı açısından en deneyimli öğretmen olan Ö3 ise ölçmeye dair tahmin becerisi konularında nasıl stratejiler kullandığı sorulduğunda, yüzey alanı için "tabandaki karoları sayar ve bir karoyu ölçer [bir standart ölçme aracı ile] ve sonucu bulur." şeklinde bir açıklama yapmıştır. Bu açıklamada aslında tahmin etmekten çok yine net cevabı arama ve bulmaya yönelik işlemleri kullanmaya çalıştı̆̆ı dikkati çekmektedir.

Bununla beraber işlemsel tahminde yuvarlama neredeyse tek strateji olarak kullanılmaktadır. Ancak birkaç öğretmenin yapılan tahminlerin sonuçlarının net cevaba yaklaştırılabilmek adına “düzenleme-düzeltme stratejileri” kullandıkları da gözlemlenmiştir. Örneğin Ö1 şöyle bir açıklama yapmıştır:

Mesela 1208 ile 1190 çarptığımızda kaç olur? Şimdi çocuğun şunu algılaması lazım. Ya ben bunu onluğa yapsam şu olur, yüzlüğe yapsam şu olur. 1000 ile 1000'i çarpsam 1 milyon eder ama bu 1 milyonun biraz üzerinde yani. Gibi bir alg1 yönetimini hissetmesi lazım.

Ö3’ün işlemsel tahminlere dair verdiği cevaplarda sürekli tamsayıları kullanmasından dolayı "sayıların başka gösterimlerine (ondalıklı kesirler ve kesirler gibi) yönelik hangi stratejiler kullanılabilir?" şeklinde sorulan devam sorusuna "kesirlerde yarıma yakınlı̆̆ı temel alıyoruz, ondalıklı sayılarda da genellikle yuvarlama ya da ondalık kısmını atma şeklinde kullanıyoruz." yorumunu yapmıştır.

Diğer öğretmenler (Ö4, Ö5, Ö6 ve Ö7) kullandıkları stratejiler konusunda çok net bir açıklama yapmamakla birlikte "sayıları yuvarlama yaparak tahmin ediyoruz" açıklamasını sık sık yapmışlardır. Ö4'e sorulan devam sorularından “ondalıklı kesirlerin bölmesine dair nasıl bir strateji kullanırsınız?” sorusunda kendisinin verdiği örnek $(16,272 \div 36)$ üzerinde şöyle bir yorum yapmıştır: “ondalıklı kısmı atacak, sonra 16'nın 36'dan küçük olduğunu fark edip sıfır virgül deyip işleme başlayacaktır. Ondan sonra bunu yaptıktan sonra kısa yollarını ögretiyoruz.” Öğretmenin buradaki yaklaşımından da görülebileceği gibi öğrencinin standart bölme işlemini yapması beklenmektedir. 


\section{Sınıf içi/dışı uygulamaları}

Sınıf içinde ya da sınıf ortamı dışında yürütülen öğretim ortamlarında tahmin etmeye dair neler yapıldığının konuşulduğu görüşmelerde ortaya çıkan kavramlar şöyle sıralanabilir: yuvarlama çalışması, yaklaşık sonuç buldurma, yaklaşık uzunluk ölçümleri yapma. Her ne kadar tanımlar konusunda öğretmenlerin çoğunluğunun işlemsel tahmini öne çıkardıkları görülse de sınıf içi/dışı uygulamalarda ölçüsel tahmin becerisine dair öğretmenlerin yaptığını söylediği etkinlikler dikkat çekmektedir. Yapıldığı söylenen etkinlikler çoğunlukla uzunluk öğretimi üzerinedir. Milli Eğitim Bakanlığından emekli olmasına karşın, aynı zamanda hem kolej hem de dershanede çalışan, Ö1, eskiden öğrencileriyle yapmış olduğu bir etkinliği şöyle anlatmıştır:

uzunluk ile ilgili uygulamalar yapmak için taş attırırsınız çocuğa. Emirbeyazıt'ta çalışırken, hadi bakalım taş attın derdim çocuklara, sonra da ölçtürürdüm. Yani uzunluğu algılasınlar diye. Çocuk bir taş atar "ooo $2 \mathrm{~km}$ attım” der, sonra bir ölçtürürsün 12m'dir. Bunun sonunda algıları değiş̧iyordu tabi. Yani çocuk mesafe kavramını algılamazsa olmaz, her şey ölçülemez dimi.

Bunun ardından şimdi neden bu tarz etkinlikler yaptırmadığını sorulduğunda hem eski mekanların (boş arazi) olmadığını, hem de artık sınav odaklı dersler işlediklerini söylemiştir. Buna ek olarak Ö1, öğretmenlik yıllarının başında yaptığı bir dersteki anısına dair şunları aktarmıştır:

öğrencilerle uzunlukları işlemiştik. Sonra bir çocuğu kaldırarak hadi bana hizmetliden 1 desimetre civarında ip al gel dediğimde çocuk gidip hizmetli le birlikte geri döndü ve bana ne kadar ip istediğimi sormuş̧u. Sonra çocuklarla epey bu konu üzerinde pratik yaptık 1 desimetrenin metre ile ilişsisini ve elimizde bir metre yok iken 1 desimetreyi nasıl aşağı yukarı bulabileceğimizi..

Ö1'in işlemsel tahmin için kullandığı stratejileri açıklarken (bir önceki bölümlerde) verdiği örnekte (1208 ile 1190 çarpımı işlemi), sayıları yüzlüğe yuvarlama konusunda öğretmenin öğrencilerini tahmin etme konusunda düşünmelerini sağladığı anlaşılmaktadır. Ancak bu uygulamalara sıklıkla yer vermediğini özellikle vurgulayan Ö1 bu durumu öğretmen ve öğrenciler tarafindan tahmin becerisine yeteri kadar önem verilmemesi ile ilişkilendirmiştir.

Ö2 sınıf içinde tahmin etmeye yönelik bir etkinlik yapmadığını ancak zihinden işlem yapmaya dair uygulamaları öğrettiğini belirtmiştir. Matematiğin net cevaplar üstüne kurulu olduğunu doğru hesaplamalar yapmanın daha önemli olduğunu da vurgulayan Ö2 ifadelerinde çoğunlukla tahmin etme ile zihinden işlem yapmayı karıştırmıştır. 1968 öğretim programından bu yana hedef davranışlar arasında vurgulanan "tahmin ettirilir" ifadesine rağmen Ö2 sınıf içi/dışı uygulamalarında tahmin becerisini kullanmadığını belirtmiştir. 
Bununla beraber, Ö3 hesaplamalı tahmin ve ölçüsel tahmin ile ilgili sınıfta neler yapılabileceğini şöyle anlatmıştır:

Sayıları tahtaya yazıp yuvarlama yaptırıyorum. Ölçme için de masanın genişliğini ölçtürüyoruz karışlarla kaç $\mathrm{cm}$ gelir diye soruyorum. Ama yükseklik ölçümleri için odaların yükseklikleri standart biliyorsunuz onları biliyor çocuklar.

Buna rağmen Ö3 "Aslında bu tarz şeyleri pek sık yapmıyoruz sınıfta." yorumunu da eklemiştir. Neden yapmadıkları sorulduğunda programın yoğun olduğu, konuların yetişmediği ve sınava yönelik net cevaplı işlemlere daha çok önem verdiklerini itiraf etmiştir. Ancak tahmin etmek için nasıl stratejiler kullanılır sorusuna verdiği cevapta (tabandaki karoları sayar ve bir karoyu ölçer [bir standart ölçme aracı ile] ve sonucu bulur.) öğrencilere ölçüsel tahmin ile ilgili etkinlikler yaptırdığı anlaşılmaktadır. Buna ek olarak işlemsel tahmin için kullandığı stratejileri anlatırken Ö3 ondalıklı kesirlerin ondalık kısımlarını görmezden gelerek yaptıkları işlemlere de örnekler vermiştir. Ancak yine bunları pek sık yapmadığını da itiraf eden öğretmenin aslında ölçüsel ve işlemsel tahminler için yapılabilecek etkinliklerin farkında olduğu ancak bunları yapmayı tercih etmediği çıkarımı yapılabilir.

Benzer bir itiraf, hizmet yılı açısından 4. sırada olan Ö4'ten gelmiştir. Ö4 tahmin becerisine dair sınıf içinde hiçbir uygulama yapmadığını belirtmiştir. Sayıları yuvarlamaların öğretildiğini ancak başka da bir uygulama yapılmadığını, daha çok net cevaplı işlemler yapıldığını söylemiştir. Yine neden bu tarz uygulamalar yapmadığı sorulduğunda diğer öğretmenlerden farklı olarak; "Kolayımıza geliyor sanırım. Diğer uygulama için ekstra çalışmamız ve ögrenmemiz gerekiyor. Ancak net cevaplı işlemler zaten yıllardır bildiğimiz ve ögrettiğimiz konular.” şeklinde bir açıklama yapmıştır.

Farklı olarak Ö5 ve Ö7 her ikisi de sayılarla ilgili uygulamalar yaptığını ancak ölçüsel tahmin üzerine yapmadıklarını söylemişlerdir. İşlemlere dair zihinden sonuçları tahmin etme çalışmaları yaptıklarını belirtmişlerdir. Bu iki öğretmen 5. sınıfta işlemsel tahminin yer aldığını ancak 5. sınıf dışında tahmin becerisine dair bir uygulama olmadığını, ölçüsel tahmine dair bir konu ya da uygulamanın da öğretim programında yer almadığını savundular.

Ö6 sınıfta ölçmede tahmin ile ilgili uygulamalar yaptırdığını söylemiş ve eklemiştir: “mesela sıranızın boyunu tahmin edin göz kararı sonra da ölçün diyoruz. Önce metreyi tanıtıyoruz sonra da onu (metreyi) bilince şu kadar metre şu kadar cm diyor.” Ö5 ve Ö7'nin yaptığı yorumlara benzer şekilde sayılarda tahmin konusunun daha çok beşinci sınıflarda olduğunu söyleyen Ö6 diğer sınıflarda hesaplamalı tahmin etmeye dair bir uygulamanın 
olmadığını belirtmiştir. Ancak devam eden konuşmada beşinci sınıflarda da "problem çözümünden önce tahmin edilmesi istenebilir" yorumu Ö6'nın tahmin etmenin çeşitlerine dair farklı uygulamalar olabileceğini ancak buna rağmen uygulamadığını göstermektedir.

Ö1, Ö2 ve Ö3'ün dışında diğer öğretmenler 5. sınıf konularında çok fazla tahmin konusuna yer verildiğini vurgulamışlardır. Bu öğretmenlere göre 5. sınıfta tahmine dair yer alan kazanımlar sadece sayılarda tahminden ibarettir. Halbuki 2013 matematik dersi öğretim programında uzunluk ve zaman ölçme alt öğrenme alanında da tahmine dayalı çalışmalar yapılmasına dair şöyle bir uyarı bulunmaktadır "Çevre uzunluğunu tahmin etmeye yönelik çalışmalara yer verilir (MEB, 2013, s.9)." Katılımcılar ölçüsel tahminde sınıf içi uygulamalarını sadece uzunluk birimlerini tanıtırken kullandıklarını belirtmişlerdir. Dolayısı ile öğretmenler ölçüsel tahminde kütle, sıvı, sıcaklık gibi diğer unsurlarda tahmini kullanmamaktadırlar.

\section{Tahmin Becerilerini Önemine Dair Görüşleri}

"Tahmin becerisinin önemi nedir?" şeklinde sorulan soruya hemen hemen tüm öğretmenler işlemsel veya ölçüsel tahmin becerilerini düşünerek cevap vermek yerine günlük yaşamda karşılaşılan akıl yürütme becerilerini vurgulayarak yorum yapmışlardır. Görüşme deşifreleri incelendiğinde bu yorumları "günlük yaşam becerisi, gereksiz görülmesi ve sınavda çıkmaması” şeklinde kodlarla açıklanabilmektedir. Günlük yaşama dair verilen örnekler, akıl yürütme becerisi ve muhakeme etmeyi öne çıkartan örnekler şeklinde olmuştur. Sorulan derinleştirici soruda; "Derslerde öğretilen tahmin becerisi günlük yaşamdaki akıl yürütme becerisini kazandırır mı? Nasıl kazandırır?”; öğretmenler oldukça emin bir şekilde "evet" cevabı vermişlerdir. Matematiksel tahmin becerisinin bireyin günlük yaşamdaki akıl yürütme becerisine olumlu etkisinin olduğunu savunmuşlardır. Örneğin Ö1 şunu söylemiştir:

Sınıfta çocuklara, sizin ailenize ne kadar yük olup olmadığınızın hesabını ve tahminini yapıyor muydunuz? diye sorduğum soru ile çocukların bir ailenin geçimi için harcanan paranın hesabını yapmasını ve kendi harcamalarının ayarını yapmasını bekliyorum. Bu işte bir gerçek hayat tahminidir. Bunu yapabilmesi için de tahmin becerisini öğrenmesi gerekir ki bu da onun önemi gösterir dimi”.

Benzer şekilde Ö6 da derslerde tahmin becerisinin öğretilmesinin öğrencilerin günlük yaşamda daha doğru kararlar almasına yardımcı olacağını öne sürmüştür. Tahmin becerisi konusunda çok olumlu bir yaklaşım sergilemese de Ö2, semt pazar yerlerinde konulmuş tartı aletlerine dikkat çekerek bu cihazların alışveriş yaparken eksik tartılmış ürünlerin kontrol edilmesi için konulduğunu, ancak oraya gidip kontrol etmek için önce kişinin elinde tuttuğu 
torbanın kütlesinin almak istediği miktarla örtüşüp örtüşmediğini "hissetmesinin” gerektiğini vurgulamıştır. Ö2'den "hissetmek” ifadesini açıklaması istendiğinde "işte canım bakacak kaldıracak söyle bir $3 \mathrm{~kg}$ geliyor mu gelmiyor mu hissedecek” diye eklemiştir. $\mathrm{Bu}$ açıklamadan öğretmenin hissetmek derken bireyin ölçüsel tahmin becerisini kastetmiş ve bir referans geliştirmiş olması gerektiğini ve bu referansa göre alınan ürünün miktarının az/çok olduğunun fark edilebilmesi gerektiğini belirtmiştir. Tahmin etmenin günlük yaşamda önemli olduğunu düşünen Ö2 buna rağmen derslerde net cevaba dayalı matematik yapılması gerekliliğini savunmuştur.

Sonuç olarak tahmin becerisinin önemi tartışılmaz şekilde tüm öğretmenler tarafından onaylanmaktadır. Tahmin etme becerisini matematik dersi içinde önemli bir uygulama olarak görmeyen bir öğretmenin bile yaşam içerisinde bu beceriye ihtiyaç duyulduğunu, kendi tecrübe ve gözlemlerinden yola çıkarak ortaya koymuş olması bu tema altında ortaya çıkan önemli bir bulgudur.

\section{Tahmin Öğretiminde Karşılaştıkları Zorluklar}

Öğretmenlere tahmin becerisinin öğretimde karşılaşılan zorluklara dair sorularda görüşme deşifreleri "inanmamak, temel aritmetik bilgisi, öğretim programlarının yoğunluğu” kodları altında toplanan fikirler ortaya çıkmıştır. Örneğin Ö1'in bu zorluklara dair verdiği cevaplar onun kendi yaptığı gözlemler ve deneyimlerine dayanırken, ortaya koyduğu neden tahmin öğretiminin en büyük çıkmazlarından biri olarak kategorize edilebilmektedir. Çünkü Ö1 oldukça net bir şekilde bu konunun öğretimindeki en önemli sorunun öğretmenlerin konuya dair olumlu tutum sahibi olmamaları yani konunun önemine inanmamaları olduğunu ortaya koymuştur.Ö1'e göre; “[öğretmenlerin] zorlanmalarının nedeni tahmine inanmamalarıdır. Hem sunan buna inanmıyor hem de dinleyen buna inanmıyor. Zaten sunan buna inanmazsa yaşayan hiç inanmaz."

Ö1 yukarıdaki yorumuna, öğretmenler tarafından değerli ve önemli olanın net cevaplı işlemler, kontrolü kolay durumlar ve herhangi bir yoruma açık olmayan sonuçlar olduğunu da eklemiştir. Görüşme boyunca genel olarak net cevaplı matematiksel işlemlerin önemini vurgulayan Ö2, her ne kadar günlük yaşamdaki bazı tahmin gerektiren durumlara örnekler verse de bu becerinin günlük yaşamda etkili kullanılmasının arkasında net cevaplı matematiksel uygulamaların doğru ve anlamlı öğrenilmesi gerekliliği yattığını vurgulamıştır. Ona göre çocuklar günlük hayatta "matematik yapmayı" öğrenirse tahmin etme becerisine de sahip olabilirler. Onun sözleri ile, 
öğrenciler zorlanıyorlardı tabi. ...öğretmen öğrenciye öğretirken eksik öğretiyordu. İşlemlere çok önem vermek gerekiyor. Öğretmenler matematik öğretiyorlar ama günlük hayatta kullanacağı matematiği öğretemiyorlar. Önce çocukların toplama, çıkarma işlemsel becerilerini geliştirmeli, bunlar çok zayıf. Matematiksel mantık bilgileri çok zayıf. Bunun için derste öğretmen bol bol alıştırma yapmalı. Ama hepsi denklem çözüyor, ezberden yapıyorlar hepsini, matematik yapıyor sanıyorlar.

30 yıllık meslek yaşantısı olan, Ö4'e göre öğretim programlarının çok yoğun olması nedeniyle öğretmenler tahmin becerisini arka planda bırakıyorlar. Bu nedenle öğrenciler de bu konuyu öğrenemiyorlar. Aynı zamanda net cevaplı işlemlerle uğraşmanın öğretmenlerin kolayına geldiğini de belirten Ö4, aslında öğrencilerin ne anlatılırsa anladıklarını ve yeni nesil öğrencilerin çok akıllı olduklarını, tahmin gerektiren konuyu da çok kolaylıkla anlayabileceklerini, karşılaşılan zorlukların çocuklardan değil öğretmenlerden kaynaklandığını belirtmiştir. Ö4 de "öğrenme zorlukları” diye bir şeyin olmadığını aslında öğretmenlerin “öğretme zorluklarının” varlığını, bunun temelinde de öğretmeye hevesli olmamanın yattığını söyleyerek, Ö1'in düşüncelerine benzer bir durum ortaya koymuştur.

Ancak bir taraftan da tahmin becerisi ile zihinden işlemleri sık sık birbirinin yerine kullanan birkaç öğretmen (Ö3, Ö5 ve Ö6) bu becerinin öğrenciler tarafindan zorlanılacak bir beceri olmadığı hatta zihinden yapılan işlemlerin öğrenciler için eğlenceli olabileceğini, dolayısı ile bu konunun öğretmenler tarafından önemle anlatılması gerekliliğini savunmuşlardır. Ö3'e göre öğrenciler zihinden işlemlerden zevk almakta ve zorlanmamaktadırlar: "çocuklar zorlanmıyor hatta hoşuna gidiyor bu tarz kısa işlemleri ögrenmek ve akıldan hemen cevapları bulabilmek onlara zevkli geliyor."

Sonuç olarak tahmin öğretiminde karşılaşılan zorlukların temelde öğretmenlerin bu kavrama verdikleri önemle bağlantılı olduğu görülmektedir. Öğretmenlerin birçoğu bu konunun öğrenilmesinin arkasındaki sorunun aslında konuyu anlatan ve öğreten öğretmenlerin tahmin etmeye dair negatif duygu ve düşüncelerinin olduğunu belirtmişstir.

\section{Öğretmenlerin Ö̆gretim Programlarındaki Tahmine Dair Görüşler}

Görüşme soruları hazırlanırken öğretim programlarındaki değişikleri ve tahmin etmeye dair kazanımların hangi aşamalarda hangi süreçlerle kazandırılabileceğine dair öğretmen görüşleri alınmak istemiştir. $\mathrm{Bu}$ amaçla, öncelikle öğretim programlarında oluşan değişiklikleri nasıl ve nereden takip ettikleri sorgulanmıştır. Görüşmelerde ortaya çıkan fikirler "uygulanmayan kurallar ve ders kitabı" kodları altında toplanabilir. 
Katılımcıların hepsi öğretim programlarının değişikliklerini ders kitaplarından takip ettiklerini belirtmişlerdir. İnternetten öğretim programlarının incelenip incelenmediği sorgulandığında ise Ö2 ve Ö3 aşağıdaki yorumları sırasıyla yapmışlardır:

Öğretim programlarını elinize alıp incelemedik. Ancak eskiden okullarla Tebliğler Dergisi gelirdi ve onları okurduk incelerdik. Orada tüm her şey yazardı. Şimdi ders kitaplarından konuları takip ediyoruz.

Ders kitaplarını inceliyoruz yeni bir şey var mı diye...Zümre olarak otuyoruz ve birlikte tartışıyoruz neler yapılacak diye, neler değişti, neler aynı diye.

Ö5, Ö6 ve Ö7 de benzer şekilde öğretim programlarını doğrudan incelemediklerini ancak ders kitaplarından konuları nasıl değiştiğini takip ettiklerini söylemişlerdir. Ö4 öğretim programlarını kişisel olarak hiç incelemediğini, olan herhangi bir değişikliği programlardan değil ders kitaplarından öğrendiğini söylemiş ve şöyle bir yorum eklemiştir:

Konuların değişmediğini biliyorum ama konuların veriliş şekli değişti. Bunun için de değişik kitaplar, test kitapları ya da kaynak kitaplar inceliyorum ama konular çok fazla değişmediği için aynı şekilde gidiyorum, aynı şekilde anlatıyorum.

Aynı öğretmene internetten öğretim programlarını inceleyip incelemediğini sorulduğunda “onu yapmıyoruz o konuda tembeliz” diyerek bir öz eleştiri yapmıştır.

Ancak bazı öğretmenler tahmin becerisinin öğretilmesine dair yaptıkları yorumlardan anlaşılacağ́ gibi tahmin becerisinin yeni öğretim programlarının bir unsuru olduğunu ama eski matematik dersi öğretim programlarında bu tarz bir becerinin yer almadığını savunmuşlardır. Örneğin, Ö2 başta olmak üzere Ö3 yeni öğretim programlarında bu tarz etkinliklerin ve kavramların daha yoğunlukla karşısına çıktığının altını çizmiştir. Ö2, 1965 yılında Eğitim Enstitüsünden mezun olmuş ve 32 yıllık mesleki yaşantısı boyunca farklı illerde farklı ortaokullarda matematik öğretmenliği yapmıştır. 1997 y1lında emekli olan Ö2, o zamanlarda etkinlikler yapmadığını, ancak zihinden net cevabı bulduracak sorular sorduğunu ve matematikte net cevapların daha önemli olması gerektiğine inandığını belirtmiştir. 1968 yılı Matematik Dersi Öğretim Programından başlayarak 1983 ve 1990 yıllarının Matematik Dersi Öğretim Programında da öğretmenlik yapmış olan Ö2, ölçüsel tahmin uygulamalarının ise zaten matematik derslerinde kullanılmadığını, sadece metre ve katlarının öğretildiğini belirtmiştir. Ancak 1968 yılı Matematik Dersi Öğretim Programında yer alan şu ifade 
“Uzaklık ve ağırlık tahminleri yapmak ve ölçerek kontrol etmek (MEB, 1968, s.138)” Ö2'nin yorumuna ters düşmektedir.

Ö2’nin söylemlerine oldukça benzer yorumlar yapan Ö3, eskiden tahmin etkinliklerinin matematik dersinde çok yer almadığını söylemiştir. Halbuki, gerek 1983 programında açıkça ifade edilen “....bir problemin sonucunu tahmin edip söyleme veya yazma” (MEGSB, 1983, s.175), gerekse devam eden y1llardaki Matematik Dersi Öğretim Programında kullanılan şekliyle "Belirtilen bir uzunluğu, metre veya santimetre cinsinden tahmin etme" (MEB, 1998, s.289), 2000'li y1llardan önce de tahmin becerisine dair Matematik Dersi Öğretim Programında ilgili hedef ve davranışların olduğunu göstermektedir. Buna rağmen Ö3 günümüz öğretim programında sayılarda ve işlemlerde tahminin daha çok kullanıldığını ancak ölçmede tahminin daha az kullanıldığını söylemiş ve hatta durup düşünüp tekrar yorum yaparak olmadığının altını çizmiştir.

\section{Tartışma ve Sonuç}

$\mathrm{Bu}$ çalışmada nitel araştırma yaklaşımı kullanılarak bir olgunun derinlemesine araştırılmasına olanak veren olgu bilim incelemesi yapılmıştır. Yedi tane 5-8. sınıflar düzeyi matematik öğretmeninin farklılaşan öğretim programları sürecinde, tahmin becerisine dair düşünceleri, sınıfta oluşturdukları öğrenme ortamları ve uygulamaları öğretmenlerin gözünden ortaya koyulmaya çalışılmıştır. Öğretmenler ölçüt örnekleme ilkesi göz önünde bulundurularak seçilmiş ve 1968 öğretim programından bu yana yürürlükte olan ortaokul matematik dersi öğretim programında görev yapmış olanlara ulaşılmaya çalışılmıştır.

Yapılan analizlerde katılımcıların tahmine dair tanımlarında farklılıklar olduğu görülmüştür. Daha çok günlük yaşamda kullanılan şekli ile pratik kullanım alanlarını ön plana çıkaran ve sezgilere dayalı tanımlamaları tercih etmişlerdir. Formal bir tanım vermekten uzak olan öğretmenler günlük dil kullanarak çıkarımlar yapma olarak tahmini tanımlarken bazıları da zihinden hesap yapma ile karıştırmışlardır. Tahmin çeşitlerine dair genellikle sayılarda ve ölçmede tahmin konuşulmuş ancak ender olarak problem çözme stratejisi içerisinde kullanılan tahmin becerisinden bahseden öğretmenler de olmuştur. Bu bağlamda da "kontrol etme" amaçlı tahmin becerisinin kullanılması gerekliliğine vurgu yapılmıştır. Buna benzer şekilde günlük yaşamda akıl yürütmeyi gerektiren durumlarda kullanılan tahmin becerisinden bahseden öğretmenlerin yanında bazıları da ileriye dönük yargılarda bulunma ve öngörü amaçlı tahmin becerilerinden bahsetmişlerdir. Ancak mesleki hizmet süreleri oldukça farklı öğretmenlerin tahmin etmeyi zaman zaman zihinden net cevaplar bulma işlemi olarak 
düşünerek yorumlar yapması da öğretmenlerin değişen ve gelişen öğretim programlarında değişmeyen bazı matematiksel kavramlar hakkında benzer yanılgılara düştüğünü göstermektedir. Bununla beraber, 30 yılı aşmış bir mesleki yaşantısı olan bir öğretmen hemen hemen tüm öğretim programlarında ölçüsel tahminler yaptırıldığını ancak sayıların tahmini işlemleri yerine zihinden net cevaplı işlemlerin daha ön planda olduğunu belirtmiştir.

Katılımcıların tercih ettiği stratejiler arasında ölçüsel tahmin için kullanılan standart olmayan ölçümlerin yapılmasında, karış ölçümü yapmanın sıklıkla kullandıklarını belirtmişlerdir. Bunun yanında hesaplamalı tahmin becerisinde ise Reys'in (1986) çalışmasında da vurguladığı gibi bu çalışmada da benzer şekilde yuvarlama stratejisi farklı mesleki deneyim sürelerine sahip tüm öğretmenler için kullanılan tek strateji olmuştur.

Tahminin önemi konusunda hemen hemen tüm öğretmenler hem fikir iken bazıları matematiğin yapısı gereği net cevapların matematik dersi içerisinde daha önemli olduğunu ve tahminin sadece günlük yaşam uygulamalarında kullanılabileceğini öne sürmüşlerdir. Günlük yaşamda ise karar alırken ve yorum yaparken, muhakeme etme süreci içerisinde kullanımı önemsenmiştir. Günlük yaşam ile tahmin ilişkilendirmesine yönelik bu bulgu Siegel, Goldsmith, ve Madson (1982) ile tutarlıdır. Ancak, alan yazınında daha önce de belirtildiği gibi tahmin etmenin çok sayıda faydası olmasına karşın, bu çalışmadaki öğretmenlerin görüşleri çok sınırlı kalmıştır. Örneğin faydalarından bazıları esnek işlem yapabilme (NCTM, 2000), matematiğin içinde risk almayı öğretmesi (Adams, vd., 2005), sayı duygusu/algısını geliştirme ve bilişüstü becerileri ilerletme (Carroll, 1996) sayılabilir.

Tahminin sınıf içi/dışı uygulamaları konusunda günümüzde öğretmenlerin hemen hepsi bu tarz uygulamaları yapmadıklarını belirtmişlerdir. Bunun sebepleri arasında hem öğretim programlarındaki değişimleri takip etmemeleri, yapılabilecek etkinlik çeşitleri hususunda kendilerini yeteri kadar donanımlı hissetmemeleri ve bu tarz etkinliklerin verimliliğine inanmıyor olmaları gösterilebilir. Sınıf içi/dışı etkinlikleri uygulamaya dair farklı mesleki sürelere sahip öğretmenlerin aynı yorumları yapmalarına rağmen gerekçeleri birbirinden farklıdır. Günümüz öğretim programlarında öğretmenlik yapanların gerekçeleri zaman bulmama, öğretim programlarının yoğunluğu ya da etkinlik yapmayı tercih etmiyor olmaları iken, daha eski öğretim programlarından bu yana öğretmenlik yapan öğretmenlerin bu tarz etkinlikleri kullanmamalarının nedeni ise tahmin etme konusunu zihinden net işlemler yapma konusu ile karıştırmaları sonra da sınav sistemi içerisinde tahmin etmeye dair sorularla karşılaşmayacaklarına olan inançları gösterilebilir. 
Tahminin öğretiminde karşılaşılan zorluklar teması altında en çarpıcı yorumlardan bir tanesi toplumda sıklıkla yaşanan değişimler ve istikrarsız oluşumlar nedeniyle "tahmin etme" konusunun öğrenilmesi ya da öğretilmesinin önemsiz hissedilmesidir. Öğretmen ve öğrencilerin tahmin etme olgusuna inanmamaları bu konunun öğretilmesinde en büyük zorluklardan birisi olarak ortaya çıkmaktadır. Dolayısı ile karşılaşılan zorluklar aslında ne konunun epistomolojik yapısından ne de öğrencilerin psikolojik durumlarından kaynaklanmaktadır. Yaşanılan zorlukların temelinde öğretmenlerin konuya dair inançlarının olumsuz olması ve matematik öğretiminde net ve tek doğru cevabı olan durumların yer alması gerekliliği inancına sahip oldukları söylenebilir. Mesleki süresine göre daha yeni öğretmenler ise öğrencilerin tahmin etme konusunda zorluk çekmediklerini, sayıları yuvarlama konusunda oldukça başarılı olduklarını söylemeleri, mesleki deneyimi göreceli olarak daha fazla olan öğretmenlerin yaptığı öz eleştiriye yani bu becerinin önemine inanmamaları eleştirisine ters düşmektedir. Bu bağlamda öğretmenlerin tahmin etmeye dair tanımları arasındaki farklılıklar ve bu becerinin yuvarlama dışındaki stratejilerinin varlığından haberdar olma ya da olmama gibi unsurlar da bu cevaplardaki farklılıklara sebep olabilmektedir.

Öğretmenlerin matematiğe dair inançlarının öğrencilerin derslere olan inançları, tutumları ve hatta başarılarına etki ettiği bilinmektedir. Bu nedenle bu araştırmanın önemli sonuçlarından birisi öğretmenlerin tahmin becerisine dair olumsuz inançlarının varlığının ortaya konulmasıdır. Her şeyin sıklıkla değişim içinde olduğu, kuralların uzun süreli olarak uygulanamadığı, öğretim programlarının, sınav içeriğinin ve sınavın yapılış şeklinin sürekli değiştiği bir ortamda, yaklaşık değerlerle yapılan işlemler, değerlendirmeler öğretmenler tarafindan önemsenmemektedir.

Ortaokul matematik dersi öğretim programı hakkında sorulan sorulara verilen cevaplarda ise aslında öğretmenlerin değişimlerden düşünüldüğü kadar da haberi olmadığı ortaya çıkmıştır. Görüşmelere katılan öğretmenlerin hiçbiri son yıllarda değişen ve farklı öğretimsel yaklaşımları gerektiren yeni öğretim programlarını Talim Terbiye Kurulu Başkanlığının (TTKB) web sayfasından indirerek incelememiştir. Aslında bir bakıma ihtiyaç da duymamışlardır. Mesleki süresi daha fazla olan öğretmenler Tebliğler Dergisi gibi bir dergi ile öğretim programlarındaki değişiklikleri takip ettiklerini belirtmiş olmalarına rağmen günümüz koşullarında hemen hemen tüm öğretmenlerin tek bir kaynaktan (ders kitabı) programlardaki değişimleri takip etmeleri ise öğretmenleri ya teknolojiye olan mesafelerini (çünkü TTKB web sayfasını incelememiş olmaları) ya da farklı kaynaklar arayışına ihtiyaç duymamalarından kaynaklanmaktadır. Ders kitaplarının da ise ilgili kazanımların kazanım 
ifadesine yer vermemesi sadece işleniş̧lere yer vermesi nedeniyle öğretmenlerin derslerinde öğrencilere kazandırmaları gereken kazanımlar hakkında tam olarak bir fikri olmadığı sonucunu ortaya koymaktadir.

Sonuç olarak, matematik öğretmenleri ile yapılan görüşmelerden elde edilen verilere göre tahmin becerisinin önemli bir beceri olduğuna inanmalarına rağmen matematik derslerinde öğretilmesine dair olumlu görüşlerinin olmadığı sonucuna varılmıştır. Böyle bir durum da tahmin becerisinin bu duygu ve düşüncelere sahip bireyler tarafindan öğrencilere anlamlı olarak öğretilmesi ve bu öğrencilerin de tahmin etmeye ve tahmin becerisine dair pozitif duygular geliştirmeleri zor olabilir. Bu nedenle gelecek çalışmalarda öğretmenlerin bu duygu ve düşüncelerini değiştirebilecek gerek mesleki gelişim araştırmaları gerek ise farklı öğretim yöntem ve teknikleri üzerinde bilimsel çalışmalar yapılmalıdır. $\mathrm{Bu}$ olumsuz düşüncelerin nedenleri konusunda daha derinlemesine araştırmalar yürütülmeli ve konuya dair olumlu tutum kazandırılabilecek durumlar tartışılmalıdır. Ayrıca öğrencilerin de bu konu hakkındaki düşünceleri, bu düşüncelerinin altında yatan nedenler araştırılmalıdır. 


\section{Ek-1}

\section{Tema}

1. Tahmin Becerisinin Tanımı

2. Tahmin Becerisinin Çeşitleri

3. Tahmin Becerisi için Kullanılan Stratejiler

\section{Tahmin Becerisinin Önemi \\ 5. Sınıf içi/dışı Uygulamalar}

6. Öğretiminde Karşılaşılan Zorluklar

7. Öğretim Programlarındaki yeri

\section{İlgili Sorular}

Tahmin etmek/tahmin becerisi nedir?

Matematik dersinde hangi tahminlere yer vermekteydiniz?

Aşağıdaki soruları tahmin etmesini istediğinizde öğrencilerinize tahmindeki farklı stratejilere uygun sorular sorarak nasıl ögretirsiniz?

İçinde bulunduğunuz odanın yüksekliği kaç metredir? İçinde bulunduğunuz odanın karşı duvarının yüzey alanı kaç metre karedir?

İçinde bulunduğunuz odanın hacmi kaç metre küptür?

Gösterilecek bir kişinin kaç kg olduğu?

Parmaklarla oluşturulan bir açının kaç derece olduğu?

Öğrencilere tahmin becerileri kazandırılmalı mıdır? Nedeninizi açıklayınız.

Öğretmenlik yaptığınız yıllarda tahmin etme üzerine sinıfta uygulamalar yapıyor muydunuz? Evet ise bu uygulamaların içeriğinden kısaca bahseder misiniz?

Öğrencilerin tahmin etme konusunda yaşadıkları zorluklar var midır? Varsa nelerdir?

Bunların üstesinden nasıl gelmektesiniz?

Öğretim programlarında tahmin etme üzerine yazılan hedef/davranış ya da kazanımlar hakkında bilginiz var $\mathrm{m} 1$ ? Bu bilgiyi nasıl edindiniz?

Hangi matematik öğretim programlarını incelediniz? Bunlara nasıl ulaşabildiniz? 


\section{Kaynakça}

Adams, L., Onslow, B., Edmunds, G., Chapple, N., \& Waters, J. (2005). Children's development of range based estimation skills: far more than guess work. In Proceedings of the third international conference on education, Honolulu, HA.

Alajmi, A. H. (2009). Addressing computational estimation in the Kuwaiti curriculum. Teachers' views. Journal of Mathematics Teacher Education, 12(4), 263-283.

Alajmi, A., \& Reys, R. (2007). Reasonable and reasonableness of answers: Kuwaiti middle school teachers' perspectives. Educational Studies in Mathematics, 65(1), 77-94.

Balcı, A. (2006). Sosyal bilimlerde araştırma, yöntem, teknik ve ilkeler (6th ed.), Ankara: Pegem Yayıncılık.

Bestgen, B. J., Reys, R. E., Rybolt, J. F., \& Wyatt, J. W. (1980). Effectiveness of Systematic Instruction on Attitudes and Computational Estimation Skills of Preservice Elementary Teachers. Journal for Research in Mathematics Education, 11(2), 124-136.

Boz, B. (2004). Investigation of estimation ability of high school students (Unpublished Master's Thesis). Middle East Technical University, Institute of Science, Ankara.

Carroll, W. (1996). Mental computation of students in a reform-based mathematics curriculum. School Science and Mathematics, 96(6), 305-311.

Cramer, K., \& Post, T. (1993). Connecting research to teaching proportional reasoning. Mathematics Teacher, 86(5), 404-407.

Cresswell, J. W. (2008). Educational Research: Planning, Conducting, and Evaluating Quantitative and Qualitative Research. Upper Saddle River, NJ: Pearson Prentice Hall.

Creswell, J. (2013). Qualitative inquiry and research design: Choosing among five approaches (3rd ed.). USA: SAGE Publications.

Çilingir, D., \& Türnüklü, E. (2009). İlköğretim 6-8. sınıf öğrencilerinin matematiksel tahmin becerileri ve tahmin stratejileri. İlköğretim Online, 8(3), 637-650.

Dowker, A. (1992). Computational estimation strategies of professional mathematicians. Journal for Research in Mathematics Education, 23(1), 45-55.

Fang, Z. (1996). A review of research on teacher beliefs and practices. Educational Research, $38(1), 47-64$.

Ford, M. I. (1994). The teachers beliefs about mathematical problem solving in the elementary school. School Science and Mathematics, 94(6), 314-322. 
Gliner, G. S. (1991). Factors contributing to success in mathematical estimation in pre-service teachers: Types of problems and previous mathematical experience. Educational Studies in Mathematics, 22(6), 595-606.

Goodman, T. (1991). Computational estimation skills of preservice elementary teachers. International Journal of Mathematical Education in Science and Technology, 22(2), 259-272.

Gooya, Z., Khosroshahi, L. G., \& Teppo, A. R. (2011). Iranian students' measurement estimation performance involving linear and area attributes of real-world objects. ZDM Mathematics Education, 43(5), 709-722.

Hanson, S., \& Hogan, T. (2000). Computational estimation skill of college students. Journal for Research in Mathematics Education, 31(4), 483-499.

Kagan, D. M. (1992). Implication of research on teacher belief. Educational Psychologist, $27(10), 65-70$.

Kılıç, Ç., \& Olkun, S. (2013). İlköğretim öğrencilerinin gerçek yaşam durumlarındaki ölçüsel tahmin performansları ve kullandıkları stratejiler. Illköğretim Online, 12(1), 295-307.

Lemaire, P., \& Lecacheur, M. (2002). Children's strategies in computational estimation. Journal of Experimental Child Psychology, 82(4), 281-304.

Lemaire, P., Lecacheur, M., \& Farioli, F. (2000). Children's strategies in computational estimation. Canadian Journal of Experimental Psychology, 54(2), 141-148.

Lesh, R., Hoover, M., Hole, B., Kelly, A., \& Post, T. (2000). Principles for Developing Thought-Revealing Activities for Students and Teachers. In A. Kelly, \& R. Lesh (Eds.), Research design in mathematics and science education (pp. 591-646). Mahwah, New Jersey: Lawrence Erlbaum Associates.

Levine, D. R. (1982). Strategy use and estimation ability of college students. Journal for Research in Mathematics Education, 13(5), 350-359.

Lingefjärd, T. (2006). Faces of mathematical modeling. ZDM, The International Journal on Mathematics Education, 38(2), 96-112.

Liu, F. (2009). Multiplication estimation by third and fifth-grade Chinese students. School Science and Mathematics, 107(9), 325-337.

MEB [Milli Eğitim Bakanlığı]. (1948). İlkokul programı. İstanbul: Milli Eğitim Basımevi.

MEB. (1968). Illkokul programı. Ankara: Ayyıldız Matbaası. 
MEB. (1998). Illköğretim okulu matematik dersi öğretim programı: 1-2-3. sinıflar. Ankara: Milli Eğitim Basımevi.

MEB. (2006). İlköğretim İngilizce Dersi (4,5,6,7 ve 8.sinıflar) öğretim programı. Retrieved from http://ttkb.meb.gov.tr.

MEB. (2009a). İlköğretim matematik dersi (1.-5. sinıflar) öğretim programı. Retrieved from http://ttkb.meb.gov.tr.

MEB. (2009b). İlköğretim matematik dersi (6.-8. sınıflar) öğretim programı. Retrieved from http://ttkb.meb.gov.tr.

MEB. (2009c). Illkögretim fen ve teknoloji dersi (1.-5. sinıflar) öğretim programı. Retrieved from http://ttkb.meb.gov.tr.

MEB. (2009d). Illköğretim Türkçe dersi (1.-5. sinıflar) öğretim programı. Retrieved from http://ttkb.meb.gov.tr.

MEB. (2013). Ortaokul matematik dersi (5, 6, 7 ve 8. sinıflar) öğretim programı. Retrieved from http://ttkb.meb.gov.tr.

MEB. (2015). Illkokul matematik dersi (1, 2, 3 ve 4. sinıflar) ögretim programı. Retrieved from http://ttkb.meb.gov.tr.

MEGSB (Milli Eğitim Gençlik ve Spor Bakanlığı). (1983). Illkokul matematik programı. İstanbul: Milli Eğitim Basımevi.

Micklo, S. J. (1999). Estimation: It's more than a guess. Childhood Education, 75(3), 142145.

Miles, M. B., \& Huberman, A. M. (1994). Qualitative data analysis: An expanded sourcebook (3rd ed.). Newbury Park, CA: Sage Publications.

Mohamed, M., \& Johnny, J. (2010). Investigating number sense among students. Procedia Social and Behavioral Sciences, 8, 317-324.

NCTM [National Council of Teachers of Mathematics]. (1989). Curriculum and evaluation standards for school mathematics. Commission on Standards for School Mathematics. Reston VA: National Council of Teachers of Mathematics.

NCTM. (2000). Principles and standards for school mathematics. Reston, VA: National Council of Teachers of Mathematics.

Osborne, J. (2005). The role of argument in science education. In K. Boersma (Ed.), Research and the Quality of Science Education (pp. 367-380). The Netherlands: Springer. 
Patkin, D., \& Gazit, A. (2013). On roots and squares - estimation, intuition and creativity. International Journal of Mathematical Education in Science and Technology, 44(8), 1191-1200.

Posamentier, A. S., \& Krulik, S. (1998). Problem-Solving strategies for efficient and elegant solutions. A Research for the Mathematics Teacher. California: Corwin Press.

Raymond, A. M. (1997). Inconsistency between a beginning elementary school teacher's mathematics beliefs and teaching practice. Journal for Research in Mathematics Education, 28(5), 550-576.

Reys, B. J. (1986). Teaching Computational Estimation: Concepts and Strategies. In H. L. Schoen \& M. J. Zweng (Eds.), Estimation and mental computation: 1986 yearbook (pp. 31-45). Reston, VA: National Council of Teachers of Mathematics.

Reys, R., Reys, B., Nohda, N., Ishida, J., Yoshikawa, S., \& Shimizu, K. (1991). Computational estimation performance and strategies used by fifth- and eighth-grade Japanese students. Journal for Research in Mathematics Education, 22(1), 39-58.

Reys, R. E., Rybolt, J. F., Bestgen, B. J,. \& Wyatt, J. W. (1982). Processes used by good computational estimators. Journal for Research in Mathematics Education, 13(3), 183 201.

Rubenstein, R. (1985). Computational estimation and related mathematical skills. Journal for Research in Mathematics Education, 16(2), 106-119.

Segovia, I., \& Castro, E. (2009). Computational and measurement estimation; curriculum foundations and research carried out at the University of Granada. Electronic Journal of Research in Educational Psychology, 7(1), 499-536.

Shulman, L. S. (1986). Those who understand: Knowledge growth in teaching. Educational Researcher, 15(2), 4-14.

Siegel, A. W., Goldsmith, L. T., \& Madson, C. R. (1982). Skill in estimation problems of extent and numerosity. Journal for Research in Mathematics Education, 13(3), 211232.

Siegler, R. S., \& Booth, J. (2004). Development of numerical estimation in young children. Child Development, 75(2), 428-444.

Siegler, R. S., \& Booth, J. L. (2005). Development of numerical estimation: A review. In J. I. D. Campbell (Ed.), Handbook of mathematical cognition (pp. 197-212). New York: Psychology Press. 
Smart, J. R. (1982). Estimation skills in mathematics. School Science and Mathematics, 82(8), 642-649.

Sullivan, J. L., Juhasz, B. J., Slattery, T. J., \& Barth, H. C. (2011). Adults' number-line estimation strategies: Evidence from eye movements. Psychonomic Bulletin \& Review, $18(3), 557-563$.

Tirosh, D., \& Graeber, A. O. (1989). Preservice elementary teachers' explicit beliefs about multiplication and division. Educational Studies in Mathematics, 20(1), 79-96.

Thompson, A. G. (1979). Estimating and Approximating. School Science and Mathematics, 79(7), 575-586.

Thompson, A. G. (1992). Teachers' beliefs and conceptions: A synthesis of the research. In D. A. Grouws (Ed.), Handbook of research on mathematics teaching and learning (pp. 127-146). New York: Macmillan.

Toluk-Uçar, Z., \& Aytekin, C. (2014). Investigation of middle school students' estimation ability with fractions. Illkögretim Online, 13(2), 546-563.

Tsao, Y. L., \& Pan, T. R. (2013). The computational estimation and instructional perspectives of elementary school teachers. Journal of Instructional Pedagogies, 11, 1-15.

Van de Walle J. A. (2004). Elementary and middle school mathematics: Teaching developmentally. Boston: Allyn \& Bacon.

Verschaffel, L., Greer, B., \& De Corte, E. (2007). Whole number concepts and operations. In F. Lester (Ed.), Second handbook of research on mathematics teaching and learning (pp. 557-628). Charlotte, NC: Information Age.

Y1ldırım, A., \& Şimşek, H. (2006). Sosyal bilimlerde nitel araştırma yöntemleri. (6. bask1)

Ankara: Seçkin Yayıncılık. 